\title{
The Use Of Historical Buildings For Touristic Purposes: The Case Of Karatay Madrasah
}

\author{
Elif Merve Yılmaz*, Mine Ulusoy
}

\section{ABSTRACT}

Since Turkey has hosted many civilizations in the past, it has an important cultural and historical heritage. This heritage, which is tried to be kept very careful, includes also architectural works. These historical buildings are often used with different functions. While some of them have a social transformation such as restaurants and hotels, some of them are open to visitors with the function of the museum. The Karatay Madrasah was built during the Seljuk Empire period and added value to the capital, Konya. The madrasah, which is important in the historical process, is to use museum of tile works and accept visitors today. In this study, Karatay Madrasah was explained about the change in the historical process and its use after conversion to the museum, also number of visits by years. It has been determined that it is an important contribution to cultural tourism in Konya.

\section{Keywords: Karatay Madrasah, Cultural tourism, historical heritage}

Jel Codes: Z32, $L 8$

\section{Tarihi Yapıların Turizm Amaçıı Kullanılması: Karatay Medresesi Örneği}

$$
\text { ÖZET }
$$

Türkiye coğrafyast geçmişte birçok medeniyete ev sahipliği yapmış olması sebebiyle önemli bir kültürel ve tarihi mirası barındırmaktadır. Oldukça dikkatli korunmaya çalışılan bu miras, mimari eserleri de kapsamaktadır. Tarihi yapılar, çoğu şehirde farklı işlevlerle kullanılmaktadır. Bazıları restoran ve otel gibi sosyal amaçlı dönüşüm geçirirken, bazıları müze işleviyle ziyaretçilere açılmaktadır. Karatay Medresesi, Selçuklu Imparatorluğu döneminde inşa edilmiş ve başkent olan Konya'ya değer katmıştır. Tarihsel süreçte önemi büyük olan medrese, günümüzde çini eserleri müzesi olarak kullanılmakta ve ziyaretçileri kabul etmektedir. Bu çalışmada, Karatay Medresesi'nin tarihsel süreçteki değişimi ve müzeye dönüştürüldükten sonra kullanımı anlatılmıştır. Ayrıca yıllara göre ziyaretçi sayıları da analiz edilmiştir. Konya'daki kültür turizmine önemli katkıları olduğu saptanmıştır.

Anahtar Kelimeler: Karatay Medresesi, Kültürel turizm, tarihi miras

Jel Kodları: $Z 32, L 8$ 
$\int$

Elif Merve Yulmaz, Mine Ulusoy

\section{Introduction}

Tourism research in general began to expand rapidly during the 1980s, which saw an overall and steady increase in published research on tourism (Sheldon, 1991: 483). This growth is also reflected in the field of cultural tourism. The cultural tourism bibliography compiled by the Association for Tourism and Leisure Education (ATLAS) Cultural Tourism Research Group shows that the volume of cultural tourism research has grown highly in recent decades.

Cultural tourism is one of the oldest forms of travel and still continues to be a mainstay of the tourism industry in most parts of the world. According to the OECD (2009), cultural tourism accounted for around $40 \%$ of all international tourism, or 360 million arrivals in 2007. (Richards and Musters, 2010:1)

Cultural tourism is a place of wisdom in the broad sense of history and belongs to a nation (Öztürk and Yazıcığlu, 2002: 188). According to this definition On the basis of cultural tourism lies a variety of reasons. History of old art works the observations of structures and their remains are aimed at research, exploration and travel for religious purposes, local architecture and original features, libraries, local cuisine, festivals and fairs, theater and cinema, music and dance, undergraduate and literary studies and subcultures travel increases the knowledge and visibility of people and takes place in cultural tourism. (Kizılırmak and Kurtuldu, 2005: 102)

\section{Historical Buildings and Tourism}

In countries all over the world, especially those with long history, it is seen that the places attracting the most tourists are historical monuments and local architecture. The most visited museums in Turkey are the Hagia Sophia Museum the Topkapi Palace and the Mevlana Museum which is in Konya hosts millions of people. (kulturvarliklari.gov.tr)

Konya, which has been the capital of the Seljuk Empire since its establishment, has become the most important cultural center that has kept the Seljuk art and style. It witnessed the history of many types of buildings such as palace, mosque, madrasah, tomb, fountain, bath and caravansary. Because the city hosts Seljuk artifacts, it has taken up the concept and importance of cultural heritage.

\subsection{Karatay Madrasah}

The Karatay Madrasah, built in Konya in 1251 and reached daily, has never lost its importance. The madrasah is located in the north of Alaeddin Hill, opposite to Selçuk University Rectorate Building and on Ankara Street, just near the mosque 
and mansion built on this hill in Seljuk period. The Karatay University, which is the foundation university, was founded with the mission of Karatay Madrasah.

Celaleddin Karatay, who gave the name to Madrasah, is a state man who has been honored by his honest personality, with his right decisions, and has a great reputation in the Seljuk period and is widely accepted by his strong religion. (Erdemir, 2001:14) Karatay Madrasah educated at that time many valuable Muslim hafiz and imams.

Although it is not known exactly who the architect of the Madrasah is, it is thought that the process and details similar to the Alaaddin Mosque can be seen as an influence on the construction of Mehmet bin Havlan from Damascus.

The Karatay Madrasah is different from the classical Seljuk works with its plan, architectural form, and material and appearance characteristics. Some of these features are; the distortion on the wall on the eastern facade, the use of colored marble on the crown, the difference between the main room in the entrance and the tile decorations in the entrance. (Yaldı, 2003:101)

The madrasah education started in 1253, it was also used during the Ottoman period, but was left to fate towards the end of the 19th century. (Atçeken, 1998:229)

\subsubsection{Karatay Madrasah in Historical Process}

The madrasah creates a rectangular sensation close to the square when viewed from the outside and the outer frame. The central dome has been stepped with two layers of tanks towards the outside and the skirts.

Madrasah has passed the danger of collapse several times and it rescued and restorated. Some sections are not avaible today. 
Figure 1: Karatay Madrasah, plan (2017)

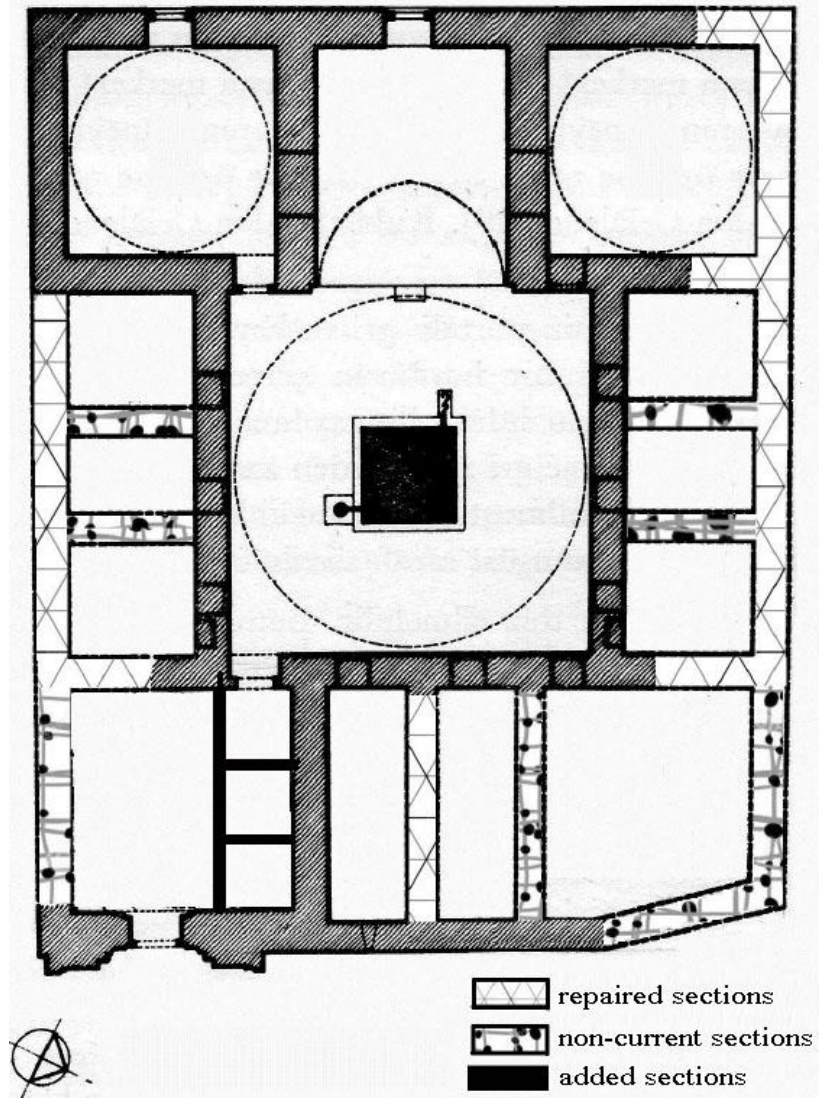

Figure 2: The Situation of Karatay Madrasah in 1980 and 2017
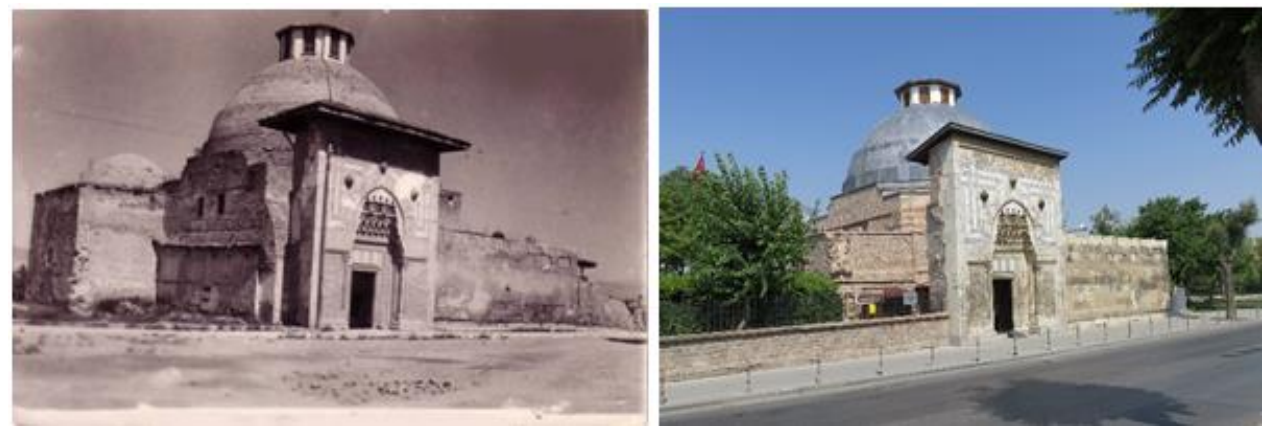

Source: (camilerveturbeler.com) 


\subsubsection{Karatay Madrasah Museum of Tile Works}

In 1955, this important historical building transformed a museum. Because of the tile works in its inside, it was approved that it should be a museum of the tile works.

The madrasah, which is used as a Museum of Tile Works today, is frequently visited by domestic and foreign visitors because it is in a very important and central position.

The madrasah, which was used effectively during the Ottoman period, was closed down by the Teaching Union Law of 1924 and was used as a museum in 1955. The Karatay Madrasah, which has undergone many restorations and has been restored, has been renovated with restoration sometimes and has not been able to accept visitors. Classification of the works in it can be done as follows;

- $\quad$ Konya Palace (II.Kılıçarslan Palace) tiles and articles

- $\quad$ Kubad Abad Palace tiles, gypsum and glass samples

- Ottoman Period ceramic ware

- $\quad$ Seljuk Period Ceramic ware

- $\quad$ The tomb of Celaleddin Karatay

Figure 3: Karatay Madrasah Museum Plan, 2001

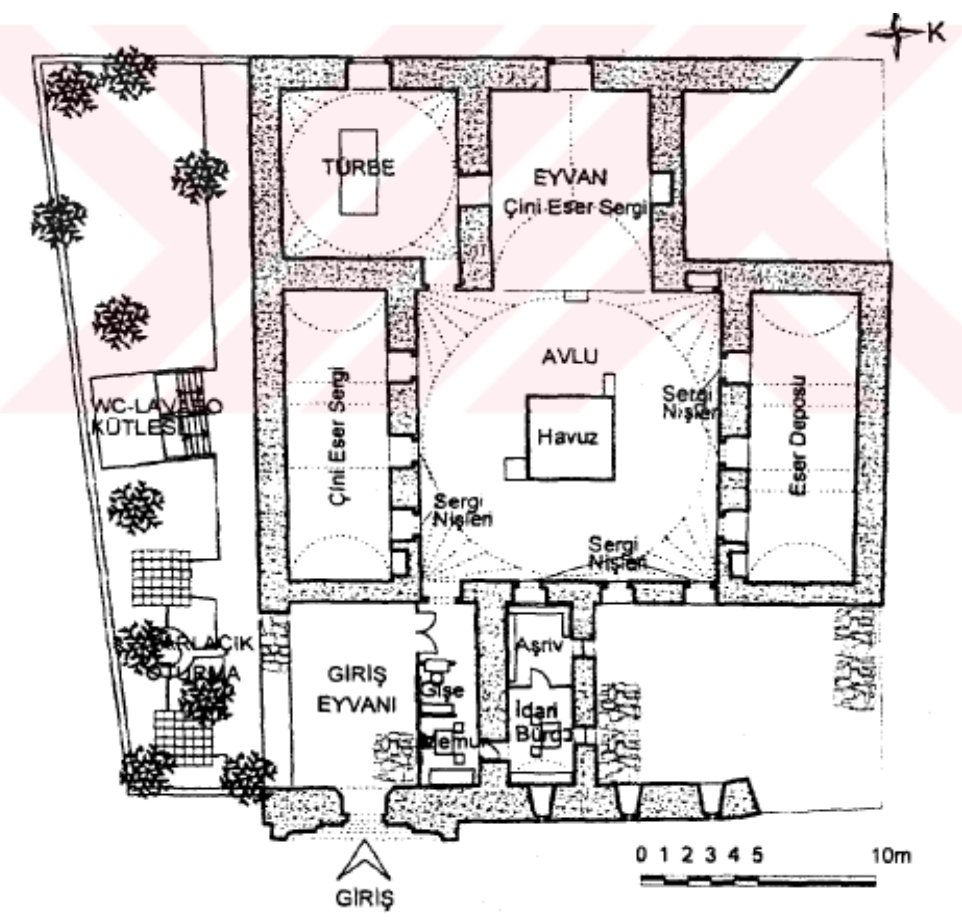

Source: (Yald1z, $2001: 118$ ) 


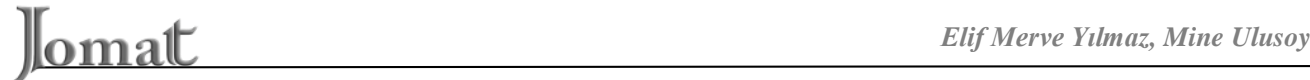

Comparing the two plans (Figure-2 and Figure-3), it can be seen that the destroyed room in the north-east was completed as a result of the work in 2006 and the works are exhibited. It is understood that the room in the south east is still rundown.

In the past there was no arrangement around it, but today there is a seating area for museum staff and afforestation.

Figure 4: Sections of the Karatay Madrasah Museum, 2017

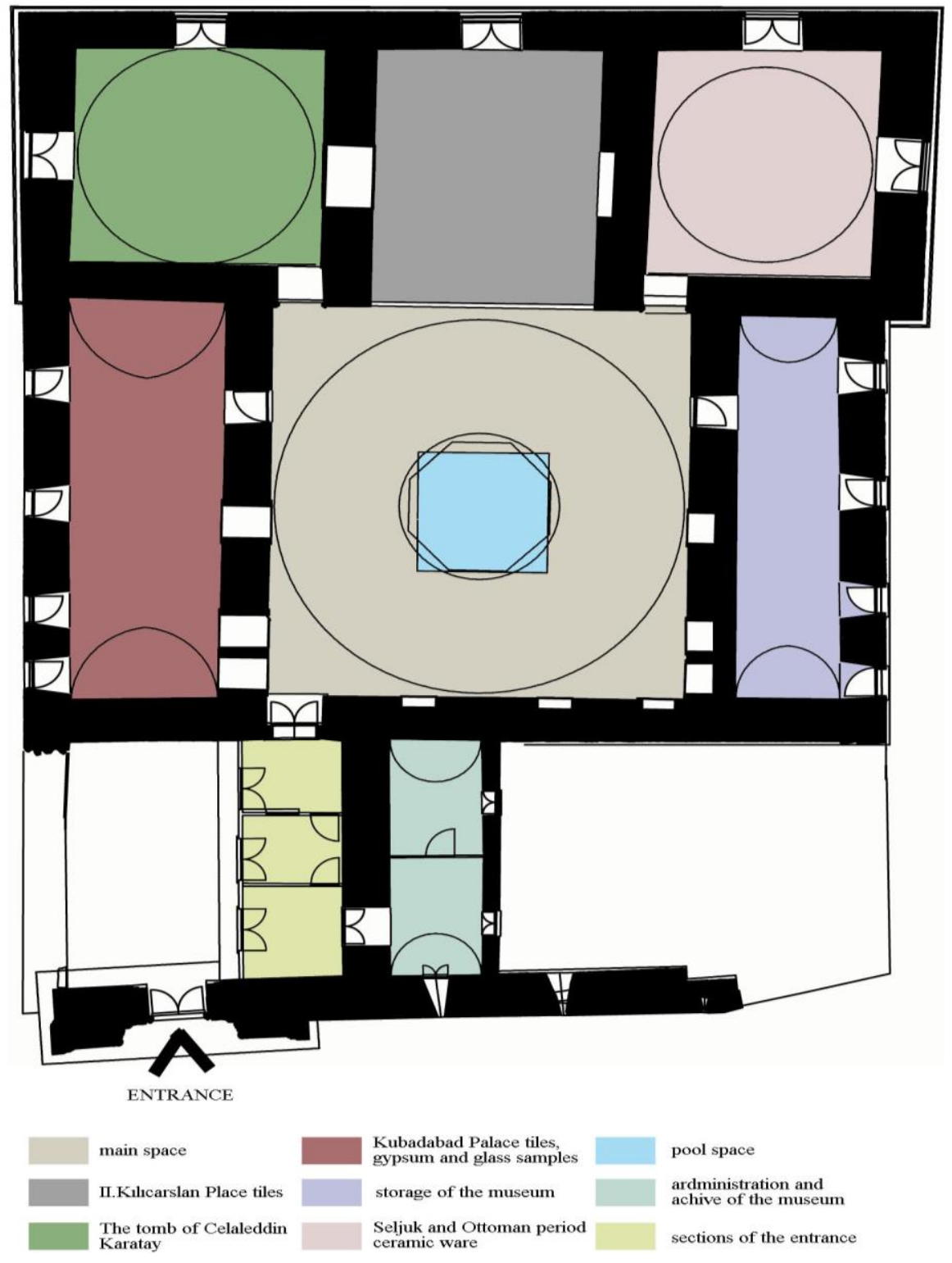


Table 1: The number of visitors of Karatay Madrasah

\begin{tabular}{|l|c|c|c|c|c|c|c|}
\hline & $\mathbf{2 0 0 5}$ & $\mathbf{2 0 0 6}$ & $\mathbf{2 0 0 7}$ & $\mathbf{2 0 0 8}$ & $\mathbf{2 0 0 9}$ & $\mathbf{2 0 1 0}$ & $\mathbf{2 0 1 1}$ \\
\hline Number of visitors & 69.377 & 18.796 & 0 & 0 & 50.900 & 71.558 & 62.934 \\
\hline & $\mathbf{2 0 1 2}$ & $\mathbf{2 0 1 3}$ & $\mathbf{2 0 1 4}$ & $\mathbf{2 0 1 5}$ & $\mathbf{2 0 1 6}$ & $\begin{array}{c}\mathbf{2 0 1 7} \\
\text { (first 6 m) }\end{array}$ & \\
\hline Number of visitors & 109.315 & 112.869 & 69.879 & 11.960 & 39.575 & 18.217 & \\
\hline
\end{tabular}

Source: (Konya Provincial Directorate of Culture and Tourism)

The location of the building also increases its accessibility and provides easy access to the visitors. The fact that it is close to the tram and bus station, walking distance to the city square, rises the tourist value.

\section{Conclusion}

According to the information obtained from the Provincial Directorate of Culture and Tourism, $4 \%$ of the annual museum visitors in Konya meet Karatay Madrasah. Besides, according to the table prepared monthly by the Provincial Directorate of Culture and Tourism, the madrasah, which has fewer visitors in the first 6 months of the year, has reached the highest number of visitors in the last 6 months, especially in Seb-i Arus (The Wedding Day). The least visitors come in January. It can be thought that it is from winter conditions. Considering the tourist attractiveness of Mevlânâ Museum by $90 \%$, the Karatay Madrasah appears to be in second place. In 2013, it reached the highest number of visitors. (Table 1) In 2016, Konya was the cultural capital of Islamic World so, more visitors came to Konya and visited museums of this city. Yet, number of visitors in 2016 could not reached desired and expected level due to some terrorist incidents in Turkey.

Furthermore, number of visitors fall on some years because it has undergone restoration in June 2006 and has never received visitors for 2 years. It was opened in January 2009. It was also restored in May 2015 and reopened in February 2016. Yet, total number of visitors is more than other museums. It is an important building of historical heritage.

It can be associated with the fact that the number of visitors to the Karatay Museum is relatively low compared to the Mevlânâ Museum which is free of charge because it is visited by buying ticket. If the museum's visitors is to be increased, it should be free of charge. Besides, the number of visitors can also increase by communicating with the tour companies and city organizations by including the programme Karatay Madrasah Museum.

It can also be thought that historical buildings do not contribute much to the number of visitors in tourism because of the restorations reasons why closed sometimes. However, many tourists tend to visit historical and cultural attractions in 
] Elif Merve Yilmaz, Mine Ulusoy

the country or region they are visiting. Rather than building new buildings, it is very important to evaluate buildings that exist and have historical value in tourism.

\section{References}

McKercher, B., and Du Cros, H. (2002), Cultural tourism: The Partnership Between Tourism And Cultural Heritage Management, Routledge.

Atçeken, Z. (1998), Konya'daki Selçuklu Yapılarının Osmanlı Devrinde Bakımı ve Kullanılması, Türk Tarih Kurumu Yayınları, Ankara.

Erdemir, Y. (2001), Karatay Medresesi Çini Eserleri Müzesi, T.C. Konya Valiliği İl Müdürlügü, Konya.

Richards. G. and Munsters, W. (2010), Cultural Tourism Research Methods, AMA Dataset, Preston: UK.

Öztürk, Y. and Yazıcıoğlu, İ. (2002), "Gelişmekte Olan Ülkeler İçin Alternatif Turizm Faaliyetleri Üzerine Teorik Bir Çalışma”, Ticaret ve Turizm Eğitim Fakültesi Dergisi, Volume 2, Ankara.

Kızılırmak, İ. and Kurtuldu, H. (2005), "Kültürel Turizmin Önemi ve Tüketici Tercihlerinin Belirlenmesine Yönelik Bir Çalışma", Ticaret ve Turizm Eğitim Fakültesi Dergisi, Volume 1, Ankara.

Sheldon, P. (1991), "An Authorship Analysis Of Tourism Research", Annals of Tourism Research 18, pp.473-484.

Yaldız, E. (2001), "Konya'daki Medrese Yapılarının Yeniden Kullanım Koşullarına Göre Değerlendirilmesi” Master Thesis, Selçuk University.

Admin (2014), Konya Karatay Medresesi, Nerededir? Nasll Gidilir?, http://www.camilerveturbeler.com/turbeler/karatay-medresesi-nerededirnasil-gidilir.html, [Accessed 7.05.2017]

http://www.kulturvarliklari.gov.tr/TR,43336/muze-istatistikleri.html, [Accessed 21.08.2017] 